\title{
National culture and the distribution of foreign aid
}

\author{
Phuong-Tra Vu ${ }^{1, *} \cdot$ Phung Bao Ngoc Van ${ }^{2}$ \\ ${ }^{1}$ Institute of Economics and Strategic Management, Vietnam \\ ${ }^{2}$ Foreign Trade University, Vietnam
}

Received: 5 January 2021

Revised: 21 June 2021

Accepted: 9 September 2021

\begin{abstract}
This paper investigates the relationship between a country's national culture and the level of aid it grants to other countries. We rely on Hofstede's culture framework to quantify national culture and find that national culture and aid are significantly related. Specifically, we show that countries having high power distance, high masculinity and high uncertainty avoidance cultures appear to refrain from engaging in foreign assistance programmes. On the other hand, high individualistic-culture countries tend to provide greater levels of foreign aid. Overall, the results imply that national culture matters in shaping the donation behaviour of aid providers.
\end{abstract}

Keywords: Aid; National Culture; Power Distance; Individualism; Masculinity; Uncertainty Avoidance

JEL Classification Codes: F35, Z1, O11, C23

"Let us remember that the main purpose of American aid is not to help other nations but to help ourselves."

Richard Nixon - Former U.S. President

\section{Introduction}

This paper examines how the prevailing national cultures of countries influence the level of aid which they grant to other nations. Arguably, aid is supposed to promote development, welfare, democracy and human rights in the recipient countries (Sato, 1994; Ali et al., 1999; Hynes and Scott, 2013). However, such foreign assistance programmes have been used increasingly by donors to achieve their own self-serving goals rather than the original purposes. Research shows that many donors consider foreign aid to be a primary tool to facilitate trade (Tuman and Ayoub, 2004), exchange scarce resources (Sato, 1994), "purchase" policy concessions (Licht, 2010) and strengthen their own national economies (Schraeder et al., 1998). For that reason, a large amount of effort has been devoted to understanding the underlying determinants of foreign assistance disbursement by donors. However, there has never been a clear answer to this question.

\footnotetext{
*Corresponding author. E-mail: phuongtrav@gmail.com.
}

Citation: Vu, P. T., and Ngoc Van, P. B. (2021) National culture and the distribution of foreign aid, Economics and Business Letters, 10(4), 359-368.

DOI: 10.17811/ebl.10.4.2021.359-368 
Would a nation's culture affect its incentives to provide foreign aid? Broadly defined, culture can be conceptualised as a set of shared values, beliefs and expected behaviours within a society (e.g., Herbig, 1994; Hofstede, 1980). It can significantly influence the common attitudes, perceptions and decision-making of citizens in a nation (Adler, 1997). Given that foreign aid is made discretionally and such decisions shall not be regulated ex ante, but influenced by common beliefs, perception and attitude embedded in societal norms of donors, we expect that the prevailing national culture affects the disbursement of aid.

In this research, we rely on the culture framework developed by Hofstede (1980) to measure the cultures of donors. Hofstede's culture framework is one of the most widely used frameworks in empirical cultural studies (Debki et al., 2018; Stojcic et al., 2016; Ashraf et al., 2016; Smith, 2015; Kanagaretnam et al., 2014; Ho et al., 2012). Accordingly, there are four classified cultural dimensions: Power Distance, Individualism, Masculinity and Uncertainty Avoidance.

Power distance refers to the extent to which the less powerful members (within a family, organisation or society) accept and expect that power is to be distributed unequally (Hofstede, 1980). On the other hand, individualistic culture tends to value personal time, freedom and independence. Those with individualistic take responsibility primarily for their own interests because they believe that personal gains are more important than the group interests (Hofstede, 1980; Ho et al., 2012). Meanwhile, masculinity refers to the distribution of roles between the genders. This culture dimension focuses on the relative importance of assertiveness, self-centeredness, power, strength and individual achievements. Finally, the uncertainty avoidance is defined as the extent to which individuals within a society are made nervous by situations that are unstructured, unclear or unpredictable, and the extent to which these individuals attempt to avoid such situations by adopting strict codes of behaviour and a belief in absolute truth (Hofstede, 1980).

We begin by positing that a country which has higher levels of power distance culture would engage less in foreign aid programmes. This is because high power distance culture tends to accept the view that inequality exists in society and perceives that superiors are eligible to such privileges (Ho et al., 2012). Prior research (e.g., Ringov and Zollo, 2007) also shows that power distance culture is negatively associated with social and environmental initiatives.

In terms of individualism culture, as high individualistic societies tend to value their benefits over the others, it would be less likely for them to engage in aid programmes designed to support others. However, recent research demonstrates that donors can use aid to achieve their own selfserving purposes rather than its intended goals. Thus, if the distribution of foreign aid can bring individualistic donors with unique benefits that they otherwise find difficult to obtain without engaging in aid programmes, they may have a strong incentive to provide more aid. Therefore, we predict that high individualism countries would provide more foreign assistance in order to pursue their own benefits.

Regarding the masculinity culture, we predict that a country having a high masculinity culture would pay less attention than others to giving aid. Masculinity culture embraces the relative importance of assertiveness, self-centeredness and individual achievements (masculine values) over the essence of compassion, helpfulness and social support (feminine values) (Ho et al., 2012). Unethical behaviour is often perceived to be high in a masculinity society as members of this society tend to be greedy and aggressive in their attempts to obtain financial gains (Vitell and Festervand, 1987). Earlier research (e.g., Ho et al., 2012) also shows that highly masculine societies are associated with lower social responsibility.

Finally, we hypothesise that uncertainty avoidance and foreign aid are negatively associated. High uncertainty avoidance societies are less tolerant to uncertainty and ambiguity, and thus tend to be more rule- and routine-oriented. Research (i.e., Ringov and Zollo, 2007) shows that members of this society may find that it is difficult to adapt when faced with novel social and environmental initiatives. Since a foreign assistance programme is an emerging concept that is 
associated with high cost and uncertain benefits, this decision is possibly less likely to be accepted in high uncertainty avoidance societies. Earlier researches (e.g., Ringov and Zollo, 2007; Parboteeah et al., 2012) also document a negative or insignificant relationship between uncertainty avoidance and sustainability initiatives.

In a cross-country analysis of thirty countries, we show that countries having a high power distance, high masculinity and high uncertainty avoidance cultures are associated with lower aid provided. On the other hand, higher aid distribution is significantly associated with cultures characterised by high individualism. Our results are consistent across a number of robustness tests.

The rest of this paper is organised as follows: Section 2 discusses data and model specification, Section 3 presents the empirical results, Section 4 provides some robustness tests and Section 5 concludes the paper.

\section{Model specification and data}

\subsection{Model specification}

To investigate how a nation's culture influences the level of aid it provides, the following baseline specification is used:

$$
A I D_{i t}=\beta_{0}+\beta_{1} C_{U L T U R E_{i t}}+X_{i, t-1}+\rho_{t}+\varepsilon_{i t}
$$

where $A I D_{i t}$ is the dependent variable and captures the level of official development assistance provided by country $i$ at time $t$. It is measured as the ratio of net official development assistance (ODA) to GDP. CULTURE $E_{i t}$ is the main independent variable of interest, capturing cultures of donors. It is one of Hofstede's (1980) culture dimensions, including POWER DISTANCE, INDIVIDUALISM, MASCULINITY and UNCERTAINTY AVOIDANCE. Follow literature (e.g., Mourouzidou-Damtsa et al., 2017), we rescale these cultural indexes so that our cultural variables range between zero and one.

It is worth noting that, national culture is hardly changed, and even when it does, these changes are likely to be gradual and take place over a very long period of time. Specifically, Hofstede suggests that cultural changes basic enough to invalidate his scores will only happen either over a period of at least 50 to 100 years, or under dramatic outside influences. Follow this line of argument and other studies (Debski, 2018; Kanagaretnam et al., 2014), we treated culture as a time-invariant features.

$X_{i, t-1}$ is a vector of donor characteristics, which include: GDP GROWTH, POPULATION GROWTH, URBAN GROWTH, GFCF, GOVERNMENT EXPENSE, OPENNESS and NATURAL RENT. Specifically, GDP GROWTH is defined as the donor's annual GDP growth rate. POPULATION GROWTH is the annual growth rate of the total population, while URBAN GROWTH is measured as the annual growth rate of the total urban population. GFCF is the ratio of gross fixed capital formation to GDP. GOVERNMENT EXPENDITURE is the ratio of total government expenditure to GDP. To proxy for trade openness, we incorporate into our baseline model the variable OPENNESS, defined as total import and export scaled on GDP. Finally, NATURAL RENT is measured as the total natural resources rents to GDP.

To mitigate the potential endogeneity bias, we lag all right-hand-side variables for one year to utilise them as predetermined variables in our specification. The definitions and sources of all variables are presented in Table 1 . We also incorporate the year fixed effect $\left(\rho_{t}\right)$ in our model to control for any time-specific effect. $\varepsilon_{i t}$ is the robust error term.

\subsection{Data}

Our analysis is conducted using the data retrieved and merged from a number of sources. Specifically, we have collected aid data and data for other macroeconomic variables from the World Development Indicators database for the period from 1960 to 2016. We then retrieved a dataset 
of national culture from Hofstede's Values Survey Module 2013 and the Geert Hofstede website. Next, we carefully matched these data based on the name of the corresponding country and its abbreviation. After excluding all missing data, we arrive at an unbalanced panel dataset consisting of 961 observations from 30 countries, as shown in Table 1.

Table 1. Sample distribution by country.

\begin{tabular}{|c|c|c|c|}
\hline No. & Country & Observations & $\%$ \\
\hline 1 & Australia & 44 & 4.58 \\
\hline 2 & Austria & 44 & 4.58 \\
\hline 3 & Belgium & 21 & 2.19 \\
\hline 4 & Canada & 26 & 2.71 \\
\hline 5 & Czech Republic & 19 & 1.98 \\
\hline 6 & Denmark & 44 & 4.58 \\
\hline 7 & Finland & 44 & 4.58 \\
\hline 8 & France & 44 & 4.58 \\
\hline 9 & Germany & 44 & 4.58 \\
\hline 10 & Greece & 20 & 2.08 \\
\hline 11 & Hungary & 13 & 1.35 \\
\hline 12 & Ireland & 42 & 4.37 \\
\hline 13 & Italy & 38 & 3.95 \\
\hline 14 & Japan & 41 & 4.27 \\
\hline 15 & Korea, Rep. & 29 & 3.02 \\
\hline 16 & Luxembourg & 36 & 3.75 \\
\hline 17 & Netherlands & 43 & 4.47 \\
\hline 18 & New Zealand & 32 & 3.33 \\
\hline 19 & Norway & 44 & 4.58 \\
\hline 20 & Poland & 18 & 1.87 \\
\hline 21 & Portugal & 36 & 3.75 \\
\hline 22 & Slovak Republic & 17 & 1.77 \\
\hline 23 & Slovenia & 11 & 1.14 \\
\hline 24 & Spain & 21 & 2.19 \\
\hline 25 & Sweden & 44 & 4.58 \\
\hline 26 & Switzerland & 31 & 3.23 \\
\hline 27 & Thailand & 10 & 1.04 \\
\hline 28 & Turkey & 17 & 1.77 \\
\hline 29 & United Kingdom & 44 & 4.58 \\
\hline \multirow[t]{2}{*}{30} & United States & 44 & 4.58 \\
\hline & Total & 961 & 100.00 \\
\hline
\end{tabular}

\section{Empirical results}

\subsection{Descriptive statistics and correlation matrix}

Table 2 provides the descriptive statistics of all variables. Our dependent variable, $A I D$, has a mean value of 0.004 . Regarding the different culture dimensions, the average values of $P O W E R$ DISTANCE, INDIVIDUALISM, MASCULINITY, UNCERTAINTY AVOIDANCE are 0.427, $0.652,0.501$ and 0.629 , respectively.

Table 3 presents the correlation matrix for variables used in our analysis. The table indicates that the highest VIF is 3.66, which is far below the benchmark of 10. Thus, it confirms that multicollinearity is not a serious problem hampering our analyses. 
Table 2. Descriptive statistics.

\begin{tabular}{|c|c|c|c|c|c|c|c|}
\hline & $\mathbf{N}$ & Mean & p25 & p50 & p75 & Definition & Source \\
\hline$A I D$ & 961 & 0.004 & 0.002 & 0.003 & 0.005 & The ratio of net ODA provided to GDP & World Development Indicator \\
\hline POWER DISTANCE & 961 & 0.427 & 0.310 & 0.380 & 0.570 & $\begin{array}{l}\text { Hofstede's Power distance culture, ranged from zero to } \\
\text { one }\end{array}$ & Hofstede's website \\
\hline INDIVIDUALISM & 961 & 0.652 & 0.550 & 0.690 & 0.790 & Hofstede's Individualism culture, ranged from zero to one & Hofstede's website \\
\hline MASCULINITY & 961 & 0.501 & 0.310 & 0.570 & 0.660 & Hofstede's Masculinity culture, ranged from zero to one & Hofstede's website \\
\hline $\begin{array}{l}\text { UNCERTAINTY } \\
\text { AVOIDANCE }\end{array}$ & 961 & 0.629 & 0.480 & 0.590 & 0.850 & $\begin{array}{l}\text { Hofstede's Uncertainty avoidance culture, ranged from } \\
\text { zero to one }\end{array}$ & Hofstede's website \\
\hline GDP GROWTH & 961 & 0.026 & 0.012 & 0.027 & 0.040 & Annual GDP growth rate & World Development Indicator \\
\hline $\begin{array}{l}\text { POPULATION } \\
\text { GROWTH }\end{array}$ & 961 & 0.006 & 0.002 & 0.005 & 0.009 & Annual growth rate of total population & World Development Indicator \\
\hline URBAN GROWTH & 961 & 0.009 & 0.004 & 0.008 & 0.013 & Annual growth rate of total urban population & World Development Indicator \\
\hline GFCF & 961 & 0.235 & 0.208 & 0.231 & 0.255 & The ratio of gross fixed capital formation to GDP & World Development Indicator \\
\hline $\begin{array}{l}\text { GOVERNMENT } \\
\text { EXPENSE }\end{array}$ & 961 & 0.326 & 0.252 & 0.343 & 0.396 & The ratio of total government expenses to GDP & World Development Indicator \\
\hline OPENNESS & 961 & 38.895 & 25.046 & 31.979 & 46.853 & The ratio of import and export to GDP & World Development Indicator \\
\hline NATURAL RENT & 961 & 0.010 & 0.001 & 0.004 & 0.010 & The ratio of total natural resources rents to GDP & World Development Indicator \\
\hline
\end{tabular}

Table 3. Correlation matrix.

\begin{tabular}{|c|c|c|c|c|c|c|c|c|c|c|c|c|c|}
\hline & & 1 & 2 & 3 & 4 & 5 & 6 & 7 & 8 & 9 & 10 & 11 & VIF \\
\hline 1 & POWER DISTANCE & $-0.411 *$ & 1.000 & & & & & & & & & & 1.75 \\
\hline 2 & INDIVIDUALISM & $0.347 *$ & $-0.453^{*}$ & 1.000 & & & & & & & & & 2.64 \\
\hline 3 & MASCULINITY & $-0.639 *$ & $0.187 *$ & 0.030 & 1.000 & & & & & & & & 1.57 \\
\hline 4 & UNCERTAINTY AVOIDANCE & $-0.475^{*}$ & $0.639 *$ & $-0.649 *$ & $0.253^{*}$ & 1.000 & & & & & & & 2.84 \\
\hline 5 & GDP GROWTH & $-0.136^{*}$ & 0.044 & $-0.077 *$ & 0.034 & -0.041 & 1.000 & & & & & & 1.16 \\
\hline 6 & POPULATION GROWTH & $0.119 *$ & $-0.137 *$ & $0.182 *$ & -0.034 & $-0.188 *$ & $0.161^{*}$ & 1.000 & & & & & 3.66 \\
\hline 7 & URBAN GROWTH & $0.070 *$ & 0.016 & $-0.087 *$ & $-0.225^{*}$ & -0.020 & $0.151^{*}$ & $0.783^{*}$ & 1.000 & & & & 3.55 \\
\hline 8 & $G F C F$ & $-0.169 *$ & $0.083^{*}$ & $-0.329 *$ & 0.047 & $0.163^{*}$ & $0.286^{*}$ & $0.223 *$ & $0.235^{*}$ & 1.000 & & & 1.66 \\
\hline 9 & GOVERNMENT EXPENSE & $0.260 *$ & 0.002 & $0.091 *$ & $-0.189 *$ & 0.039 & $-0.233 *$ & $-0.317 *$ & $-0.314^{*}$ & $-0.497 *$ & 1.000 & & 1.89 \\
\hline 10 & OPENNESS & $0.092 *$ & $0.080 *$ & $-0.136^{*}$ & -0.019 & 0.006 & $0.099 *$ & $0.123 *$ & $0.120^{*}$ & $-0.180 *$ & $0.321 *$ & 1.000 & 1.45 \\
\hline 11 & NATURAL RENT & $0.286^{*}$ & $-0.191 *$ & $0.290^{*}$ & $-0.230^{*}$ & $-0.276^{*}$ & 0.008 & $0.243^{*}$ & $0.187 *$ & 0.037 & $-0.132 *$ & $-0.191 *$ & 1.28 \\
\hline
\end{tabular}

Note: * denote significance level at $10 \%$. 
Table 4. Baseline regression.

\begin{tabular}{|c|c|c|c|c|}
\hline & \multicolumn{4}{|c|}{ Dependent variable: Aid (measured as ODA/GDP) } \\
\hline & (1) & $(2)$ & (3) & (4) \\
\hline POWER DISTANCE & $\begin{array}{r}-0.005^{* * *} * \\
(0.000)\end{array}$ & & & \\
\hline INDIVIDUALISM & & $\begin{array}{r}0.004 * * * \\
(0.001)\end{array}$ & & \\
\hline MASCULINITY & & & $\begin{array}{r}-0.006 * * * \\
(0.000)\end{array}$ & \\
\hline $\begin{array}{l}\text { UNCERTAINTY } \\
\text { AVOIDANCE }\end{array}$ & & & & $-0.005 * * *$ \\
\hline & & & & $(0.000)$ \\
\hline GDP GROWTH & $\begin{array}{r}-0.012 * * * \\
(0.003)\end{array}$ & $\begin{array}{r}-0.015^{* * * *} \\
(0.003)\end{array}$ & $\begin{array}{r}-0.012 * * * \\
(0.003)\end{array}$ & $\begin{array}{r}-0.017 * * * \\
(0.003)\end{array}$ \\
\hline POPULATION GROWTH & $\begin{array}{r}0.018 \\
(0.021)\end{array}$ & $\begin{array}{r}-0.009 \\
(0.025)\end{array}$ & $\begin{array}{r}0.186^{* * * *} \\
(0.020)\end{array}$ & $\begin{array}{r}0.001 \\
(0.023)\end{array}$ \\
\hline URBAN GROWTH & $\begin{array}{c}0.034 * * \\
(0.014)\end{array}$ & $\begin{array}{r}0.050 * * * \\
\quad(0.015)\end{array}$ & $\begin{array}{r}-0.121 * * * \\
(0.015)\end{array}$ & $\begin{array}{r}0.047 * * * \\
\quad(0.016)\end{array}$ \\
\hline$G F C F$ & $\begin{array}{r}-0.001 \\
(0.002)\end{array}$ & $\begin{array}{r}0.004 \\
(0.003)\end{array}$ & $\begin{array}{r}-0.007 * * * \\
(0.002)\end{array}$ & $\begin{array}{r}0.005 * * \\
(0.002)\end{array}$ \\
\hline GOV EXPENSE & $\begin{array}{r}0.007 * * * \\
\quad(0.001)\end{array}$ & $\begin{array}{r}0.007 * * * \\
\quad(0.001)\end{array}$ & $\begin{array}{r}0.002 * * \\
(0.001)\end{array}$ & $\begin{array}{r}0.009 * * * \\
(0.001)\end{array}$ \\
\hline OPENNESS & $\begin{array}{r}0.000 * * * \\
(0.000)\end{array}$ & $\begin{array}{r}0.000 * * * \\
(0.000)\end{array}$ & $\begin{array}{r}0.000 * * * \\
(0.000)\end{array}$ & $\begin{array}{c}0.000^{*} \\
(0.000)\end{array}$ \\
\hline NATURAL RENT & $\begin{array}{r}0.036 * * * \\
(0.005)\end{array}$ & $\begin{array}{r}0.036 * * * \\
(0.005)\end{array}$ & $\begin{array}{r}0.020 * * * \\
(0.003)\end{array}$ & $\begin{array}{r}0.028 * * * \\
(0.005)\end{array}$ \\
\hline Constant & $\begin{array}{r}0.003 * * * \\
(0.001)\end{array}$ & $\begin{array}{r}-0.003 * * * \\
(0.001)\end{array}$ & $\begin{array}{r}0.008 * * * \\
\quad(0.001)\end{array}$ & $\begin{array}{r}0.002 * * * \\
\quad(0.001)\end{array}$ \\
\hline Year FE & YES & YES & YES & YES \\
\hline Observations & 961 & 961 & 961 & 961 \\
\hline
\end{tabular}

Note: Robust standard errors are in parentheses. $* * *, * *$ and $*$ denote significance levels at $1 \%$, $5 \%$, and $10 \%$ respectively.

Table 5. Countries giving the most and the least aid.

\begin{tabular}{|c|c|c|c|c|}
\hline \multicolumn{5}{|c|}{ Panel A: Country giving the most aid $\left(75^{\text {th }}\right.$ percentile) } \\
\hline & $\begin{array}{c}\text { POWER } \\
\text { DISTANCE }\end{array}$ & INDIVIDUALISM & MASCULINITY & $\begin{array}{c}\text { UNCERTAINTY } \\
\text { AVOIDANCE }\end{array}$ \\
\hline Denmark & 0.18 & 0.74 & 0.16 & 0.23 \\
\hline Netherlands & 0.38 & 0.80 & 0.14 & 0.53 \\
\hline Sweden & 0.31 & 0.71 & 0.05 & 0.29 \\
\hline \multicolumn{5}{|c|}{ Panel B: Country giving the least aid $\left(25^{\text {th }}\right.$ percentile $)$} \\
\hline Korea, Rep. & 0.60 & 0.18 & 0.39 & 0.85 \\
\hline Thailand & 0.64 & 0.20 & 0.34 & 0.64 \\
\hline Turkey & 0.66 & 0.37 & 0.45 & 0.85 \\
\hline
\end{tabular}

\subsection{Empirical results}

Table 4 presents the results of panel models examining the impact of national culture on the level of aid provided. Columns 1 to 4 exhibit the results when the culture dimensions are each respectively incorporated into models.

Overall, the results provide support to our hypotheses. As can be seen from the table, the estimated coefficients on POWER DISTANCE, MASCULINITY, and UNCERTAINTY AVOIDANCE are negative and statistically significant. Thus, this implies that countries with a 
culture of power distance, masculinity and uncertainty avoidance offer lower levels of foreign aid programmes. For power distance culture, the result is in line with the idea that countries having high power distance culture are more tolerating towards inequality, and so are less likely to take the initiative in supporting less developed nations. Furthermore, our result is in accordance with the notion that high masculinity inhibits helping behaviour (Tice and Baumeister, 1985), and therefore countries with this cultural characteristic tend to engage less in foreign aid programmes. These ideas are also supported by the findings of recent studies (Ho et al., 2012; Ringov and Zollo, 2007) that power distance and masculinity cultures have a negative effect on social responsibility. Regarding uncertainty avoidance, the result reinforces the idea that, since high-uncertainty avoidance nations may have difficulties in adapting to novel initiatives (Ringov and Zollo, 2007), they might not favour the high costs yet uncertain benefits regularly associated with foreign aids.

On the other hand, since the estimated coefficient on INDIVIDUALISM is positive and statistically significant, it appears that higher foreign aids were provided by countries which have a high individualism culture. This is not a surprising result given that individualism countries could have high incentives to provide aid if this decision allows them to pursue their own interests. Taking the United States as an example, it is a highly individualistic country, where its scores for INDIVIDUALISM, POWER DISTANCE, MASCULINITY, and UNCERTAINTY $A V O I D A N C E$ are $0.91,0.4,0.62$ and 0.46, respectively. However, the US has always been one of the world's largest donors. As stated by the former US president Nixon, 'the main purpose of US foreign assistance programmes is to help their own benefits rather than the others'.

Data from countries of the lowest and highest aid-giving level further supports our findings, as presented in Table 5. More specifically, for countries among the $75^{\text {th }}$ percentile, their scores on POWER DISTANCE, MASCULINITY, and UNCERTAINTY AVOIDANCE are relatively low. Meanwhile, their INDIVIDUALISM scores are well above 0.7, reflecting the positive relationship between individualistic culture and aid-giving.

On the other hand, countries giving the least aid, including Republic of Korea, Thailand, and Turkey, have INDIVIDUALISM scores below 0.4. However, their scores on POWER DISTANCE and UNCERTAINTY AVOIDANCE stay well above 0.6, suggesting a negative relationship between these indexes and the level of aid given. Similarly, the MASCULINITY scores of this group are relatively high, in comparison to the top aid-givers.

Results on other control variables also provide some significant insights. Specifically, we find that countries with a higher level of government expense tend to grant more aid, as indicated by the positive and significant coefficients on GOVERNMENT EXPENSES. The estimated coefficients on OPENNESS are also positive and significant throughout the models. This therefore provides support to the proposition that many donor countries consider foreign aid as a primary tool for facilitating trade (Tuman and Ayoub, 2004). We further find that the growth rate of total population is positively associated with more aid being given to other nations.

\section{Robustness tests}

We provide several robustness checks in Table 6 to substantiate our results. Firstly, in columns 1 to 4, we employ alternative model specifications without control variables. Secondly, in columns 5 to 8, we re-estimate our baseline model (1) when adding to the regression regional fixed effects, which captures the specific characteristics of continents. Thirdly, while national culture may be persistent to change (Hofstede, 2011), one may still concern that our results can be affected by the potential endogeneity bias. To mitigate this concern, we re-estimate all the models using 2SLS estimators. We follow previous research (Ashraf et al., 2016; Ho et al., 2011) and use grammatical rule and historical prevalence of infectious diseases as instrumental variables for our 2SLS estimation. The results of the 2SLS models are presented in columns 9 to 12. Overall, the results are in line with our prior findings. 
Table 6. Robustness tests.

\begin{tabular}{|c|c|c|c|c|c|c|c|c|c|c|c|c|}
\hline & \multicolumn{4}{|c|}{$\begin{array}{l}\begin{array}{l}\text { Dependent variable: Aid Provided } \\
\text { (No controls) }\end{array} \\
\end{array}$} & \multicolumn{4}{|c|}{$\begin{array}{c}\text { Dependent variable: Aid Provided } \\
\text { (Incorporate Regional FEs) }\end{array}$} & \multicolumn{4}{|c|}{$\begin{array}{c}\text { Dependent variable: Aid Provided } \\
\text { (2SLS results) }\end{array}$} \\
\hline & $(1)$ & $(2)$ & (3) & (4) & (5) & $(6)$ & (7) & (8) & (9) & (10) & (11) & (12) \\
\hline POWER DISTANCE & $\begin{array}{r}-0.006 * * * \\
(0.000)\end{array}$ & & & & $\begin{array}{r}-0.005^{* * * *} \\
(0.000)\end{array}$ & & & & $\begin{array}{r}-0.011 * * * \\
(0.000)\end{array}$ & & & \\
\hline INDIVIDUALISM & & $\begin{array}{r}0.005 * * * \\
(0.000)\end{array}$ & & & & $\begin{array}{r}0.007 * * * \\
(0.001)\end{array}$ & & & & $\begin{array}{r}0.010 * * * \\
(0.000)\end{array}$ & & \\
\hline MASCULINITY & & & $\begin{array}{r}-0.006 * * * \\
(0.000)\end{array}$ & & & & $\begin{array}{r}-0.006^{* * * *} \\
(0.000)\end{array}$ & & & & $\begin{array}{r}-0.010^{* * * *} \\
(0.000)\end{array}$ & \\
\hline $\begin{array}{l}\text { UNCERTAINTY } \\
\text { AVOIDANCE }\end{array}$ & & & & $-0.005^{* * *}$ & & & & $-0.005^{* * *}$ & & & & $-0.007 * * *$ \\
\hline Constant & $\begin{array}{r}0.006 * * * \\
(0.000)\end{array}$ & $\begin{array}{r}0.000 * * * \\
(0.000)\end{array}$ & $\begin{array}{r}0.007 * * * \\
(0.000)\end{array}$ & $\begin{array}{r}(0.000) \\
0.007 * * * \\
(0.000)\end{array}$ & $\begin{array}{r}0.005 * * * \\
(0.001)\end{array}$ & $\begin{array}{r}-0.003^{* * * *} \\
(0.001)\end{array}$ & $\begin{array}{r}0.010 * * * \\
(0.001)\end{array}$ & $\begin{array}{r}(0.000) \\
0.005 * * * \\
(0.001)\end{array}$ & $\begin{array}{r}0.005 * * * \\
(0.001)\end{array}$ & $\begin{array}{r}-0.010^{* * * *} \\
(0.001)\end{array}$ & $\begin{array}{r}0.011 * * * \\
(0.001)\end{array}$ & $\begin{array}{r}(0.000) \\
0.003 * * * \\
(0.001)\end{array}$ \\
\hline Other Controls & $\mathrm{NO}$ & NO & NO & NO & YES & YES & YES & YES & YES & YES & YES & YES \\
\hline Region FEs & NO & $\mathrm{NO}$ & $\mathrm{NO}$ & NO & YES & YES & YES & YES & NO & NO & NO & $\mathrm{NO}$ \\
\hline Year FEs & YES & YES & YES & YES & YES & YES & YES & YES & YES & YES & YES & YES \\
\hline Observations & 961 & 961 & 961 & 961 & 961 & 961 & 961 & 961 & 961 & 961 & 961 & 961 \\
\hline
\end{tabular}

Note: Robust standard errors are in parentheses. $* * *, * *$ and $*$ denote significant levels at $1 \%, 5 \%$, and $10 \%$ respectively. 


\section{Conclusion}

This paper investigates the impact of national culture on aid provided. Our findings show that national culture does have an important influence on aid provided. However, each cultural dimension may affect the level of aid granted differently. While donors having a higher individualistic culture are proven to be more generous in aid-granting, a high power distance culture is associated with a significantly lower level of foreign aid granted. Similarly, the level of foreign aid granted by a donor characterised by having a high masculinity culture or a high uncertainty avoidance culture are also significantly lower.

Overall, our findings confirm that national culture does affect the donor country's decision in granting foreign aid. In this regard, our paper contributes to the relatively limited literature on the distribution of aid based on cultural factors. Our study also suggests various avenues for further studies into the culture-aid relationship. Future research exploring the effects of culture and aid should also consider the type (and quality) of the aid being granted. They should also investigate whether the aid provided by a donor having a certain culture actually helps or is a hindrance to the development of the recipient country.

\section{References}

Adler, N. J. (1997) International Dimensions of Organizational Behaviour, Cincinnati, Ohio, SouthWestern College Publishing.

Ali, A. A. G., Malwanda, C., and Suliman, Y. (1999) Official development assistance to Africa: an overview, Journal of African Economies, 8(4), 504-527.

Ashraf, B. N., Zheng, C., and Arshad, S. (2016) Effects of national culture on bank risk-taking behavior, Research in International Business and Finance, 37, 309-326.

Debski, J., Jetter, M., Mösle, S., and Stadelmann, D. (2018) Gender and corruption: The neglected role of culture, European Journal of Political Economy, 55, 526-537.

Fincher, C. L., Thornhill, R., Murray, D. R., and Schaller, M. (2008) Pathogen prevalence predicts human cross-cultural variability in individualism/collectivism, Proceedings of the Royal Society B: Biological Sciences, 275(1640), 1279-1285.

Gradstein, M., and Chong, A. E. (2006) Who's Afraid of Foreign Aid?: The Donors' Perspective (No. 6706), Inter-American Development Bank.

Herbig, P. (1994) The innovation matrix: Culture and structure prerequisites to innovation, Westport, CT: Quorum.

Ho, F. N., Wang, H. D., and Vitell, S. J. (2012) A Global Analysis of Corporate Social Performance: The Effects of Cultural and Geographic Environments, Journal of Business Ethics, $107,423-433$.

Ho, F. N., Wang, H. M. D., and Vitell, S. J. (2012) A global analysis of corporate social performance: The effects of cultural and geographic environments, Journal of Business Ethics, 107(4), 423-433.

Hofstede, G. (1980) Culture's consequences-international differences in work-related values, Beverly Hills, London: Sage Publications.

Hofstede, G. (2011) Dimensionalizing cultures: The Hofstede model in context. Online readings in psychology and culture, 2(1), 2307-0919.

Hynes, W., and Scott, S. (2013) The Evolution of Official Development Assistance: Achievements, Criticisms and a Way Forward, OECD Development Co-operation Working Papers, No. 12, OECD Publishing.

Kanagaretnam, K., Lim, C. Y., and Lobo, G. J. (2014) Influence of national culture on accounting conservatism and risk-taking in the banking industry, The Accounting Review, 89(3), 1115-1149 
Kanagaretnam, K., Lim, C. Y., and Lobo, G. J. (2014) Influence of national culture on accounting conservatism and risk-taking in the banking industry, The Accounting Review, 89(3), 1115-1149.

Kashima, E. S., and Kashima, Y. (1998) Culture and Language The Case of Cultural Dimensionsand Personal Pronoun Use, Journal of Cross-Cultural Psychology, 29, 461-486

Lenssen, G., Perrini, F., Tencati, A., Lacy, P., Ringov, D., and Zollo, M. (2007) The impact of national culture on corporate social performance, Corporate Governance: The international Journal of Business in Society, 7(4), 476-485.

Licht, A. A. (2010) Coming into Money: The Impact of Foreign Aid on Leader Survival, Journal of Conflict Resolution, 54(1), 58-87.

Mourouzidou-Damtsa, S., Milidonis, A., and Stathopoulos, K. (2019) National culture and bank risk-taking, Journal of Financial Stability, 40, 132-143.

Parboteeah, K. P. Addae, H. M., and Cullen, J. B. (2012) Propensity to Support Sustainability Initiatives: A Cross-National Model, Journal of Business Ethics, 105, 403-413.

Ringov, D., and Zollo, M. (2007) The impact of national culture on corporate social performance, Corporate Governance, 7(4), 476-485.

Sato, Y. (1994) New Directions in Japanese Foreign Policy: Promoting Human Rights and Democracy in Asia-ODA Perspective, in The Politics of Democratization, Edward Friedman, ed., Boulder, CO: Westview Press, 102-124.

Schraeder, P. J. Steven, W. H., and Taylor, B. (1998) Clarifying the Foreign Aid Puzzle: A Comparison of American, Japanese, French, and Swedish Aid Flows, World Politics, 50(2), 294-323.

Smith, P. (2015) To Lend Helping Hands. Journal of Cross-Cultural Psychology, 46(6), 759771.

Stojcic, I., Kewen, L., and Xiaopeng, R. (2016) Does uncertainty avoidance keep charity away? comparative research between charitable behavior and 79 national cultures, Culture and Brain, 4(1), 1-20.

Tice, D. M., and Baumeister, R. F. (1985) Masculinity inhibits helping in emergencies: Personality does predict the bystander effect, Journal of Personality and Social Psychology, 49(2), 420-428.

Tuman, J., and Ayoub, A. (2004) The Determinants of Japanese Official Development Assistance in Africa: A Pooled Time Series Analysis, International Interactions, 30(1), 43-57.

Vitell, S. J., and Festervand, T. A. (1987) Business ethics: Conflicts, practices and beliefs of industrial executives, Journal of Business Ethics. 6, 111-122. 